\title{
In-vitro uptake of glucose by bovine blastocysts
}

\author{
J.-P. Renard, A. Philippon and Y. Menezo* \\ I.N.R.A.-Station Centrale de Physiologie animale, 78450 Jouy-en-Josas, and \\ *Laboratoire de Biologie, I.N.S.A., 69621 Villeurbanne, France
}

\begin{abstract}
Summary. Blastocysts, obtained from cows on Day 10-11 after oestrus, were cultured for $20 \mathrm{~h}$. Most $(81.3 \%)$ blastocysts grew in culture and about $50 \%$ took up glucose. There was no morphological difference between the blastocysts which did or did not take up glucose but development in vivo was better for blastocysts which had taken up glucose $(69 \cdot 2 \%)$ than for those which did not $(14 \cdot 2 \%)$.
\end{abstract}

\section{Introduction}

The prediction of the viability of bovine embryos is an important factor in improving the pregnancy rate after transfer. At present, morphological criteria are used to classify such embryos but this method of assessment is subjective and dependent on wide previous experience (Shea, Hines, Lightfoot, Ollis \& Olson, 1976; Trounson, Willadsen, Rowson \& Newcomb, 1976; Elsden, Nelson \& Seidel, 1978). The ability of embryos to hatch from the zona pellucida provides a simple in-vitro check of the viability of cultured embryos (Renard \& du Mesnil du Buisson, 1976). Furthermore, glucose is essential for the hatching process; zona loss is completely inhibited when glucose is replaced by pyruvate and lactate (J.-P. Renard, unpublished observations). These findings led us to study the possibility of using glucose uptake in vitro as a biochemical indicator of the viability of bovine embryos before transfer.

\section{Materials and Methods}

Blastocysts were recovered on Day 10-11 (Day $0=$ day of oestrus) from Charolais heifers induced to superovulate by a single injection of 2100 i.u. PMSG (Folligon: Intervet) followed 48 $\mathrm{h}$ later by an intramuscular injection of $750 \mu \mathrm{g}$ prostaglandin analogue (ICI 80,996). Donors were inseminated twice with frozen bull semen 56 and $72 \mathrm{~h}$ after prostaglandin injection. The 59 hatched blastocysts used for the experiment were collected by a cervical technique described elsewhere (Ozil, Heyman \& Renard, 1979), and placed in B2 medium (Menezo, 1976) for morphological examination. Within $30 \mathrm{~min}$ of collection, each embryo was placed in a sterile glass tube $(9 \times 75 \mathrm{~mm})$ in $0.5 \mathrm{ml} \mathrm{B} 2$ medium containing $600 \mu \mathrm{g}$ glucose, gassed with $90 \% \mathrm{~N}_{2}$, $5 \% \mathrm{O}_{2}, 5 \% \mathrm{CO}_{2}$ and cultured at $37^{\circ} \mathrm{C}$ for $20 \pm 2 \mathrm{~h}$.

The size of the embryo and the concentration of glucose in the medium were measured before and after culture. Size was measured with an ocular micrometer and was defined as the diameter for spherical embryos and the square root of the product of length and width for elongated embryos. Histological techniques were used to determine the number of cells in some embryos after culture. Glucose uptake was estimated by the hexokinase method (Glucoquant: Boehringer) in the medium before and after culture. When the difference in glucose concentration before and after culture was $50 \mu \mathrm{g} / 0.5 \mathrm{ml}$ or less (uptake $<2.5 \mu \mathrm{g} / \mathrm{embryo} / \mathrm{h}$ ), it was considered that there was no glucose uptake by the embryo. This figure was derived from determinations of the repeatability of the assay using B2 medium without embryo (control). 
The viability of 27 embryos which increased in size during culture was examined in vivo by single cervical transfer, using the technique described by Renard, Heyman \& du Mesnil du Buisson (1977). The onset of oestrus in the recipients was exactly synchronized with that of the donors by the injection of $500 \mu \mathrm{g}$ prostaglandin analogue. After transfer, the absence of return to oestrus and increased plasma progesterone concentrations were used for early determination of pregnancy. The presumed pregnant recipients were slaughtered between Days 45 and 52 of pregnancy for the observation of the fetuses.

Significant differences and homogeneity between samples were determined by statistical analysis using a $t$ test for differences of paired measurements and a $\chi^{2}$ test with Yates' correction for proportions. We computed the correlation coefficient between the sizes of blastocysts before and after culture.

\section{Results}

After $20 \mathrm{~h}$ in culture, 48 out of 59 embryos $(81.3 \%$ ) had increased in size (mean rate of increase $56 \%)$. From these 48 embryos, only $25(52 \cdot 1 \%)$ showed a significant uptake of glucose from the culture medium. The mean amount of glucose taken up by these embryos (Table 1) was $5.81 \pm$ $0.70 \mu \mathrm{g} / \mathrm{h}$. Considerable variability was recorded in uptake rates of embryos of the same size, but the proportions of embryos taking up glucose did not differ significantly with the final size class. The initial and final mean sizes of embryos that enlarged in culture and took up glucose did not differ from those of the 23 embryos that enlarged in culture but showed no glucose uptake (Table 2). High correlations were found between sizes before and after culture in both groups of embryos.

Table 1. Mean \pm s.e.m. amount of glucose taken up by bovine blastocysts that enlarged in culture

\begin{tabular}{lcccc}
\hline & \multicolumn{4}{c}{ Final size of embryo after culture $(\mu \mathrm{m})$} \\
\cline { 2 - 5 } & $150-300$ & $300-450$ & $450-600$ & $600-750$ \\
\hline No. of embryos cultured & 13 & 16 & 13 & 6 \\
No. taking up glucose & 7 & 9 & 6 & 3 \\
Glucose uptake $(\mu \mathrm{g} / \mathrm{h})$ & $4.36 \pm 1.06$ & $5.87 \pm 0.92$ & $7.41 \pm 2.07$ & $7.44 \pm 2.06$ \\
\hline
\end{tabular}

Table 2. Initial and final mean ( \pm s.e.m.) sizes of bovine blastocysts in relation to glucose uptake

\begin{tabular}{lccc}
\hline & $\begin{array}{c}\text { Embryos with } \\
\text { glucose uptake } \\
(\mathbf{N}=25)\end{array}$ & $\begin{array}{c}\text { Embryos with no } \\
\text { glucose uptake } \\
(\mathbf{N}=23)\end{array}$ & $\begin{array}{c}\text { Total } \\
(\mathbf{N}=48)\end{array}$ \\
\hline Initial size $(\mu \mathrm{m})$ & $312 \cdot 6 \pm 43 \cdot 1$ & $263 \cdot 1 \pm 28 \cdot 6$ & $288 \cdot 9 \pm 26 \cdot 3$ \\
Final size $(\mu \mathrm{m})$ & $* 472 \cdot 6 \pm 63 \cdot 6$ & $* 429 \cdot 5 \pm 37 \cdot 5$ & $* 452 \pm 37 \cdot 5$ \\
Increase & 160 & 166 & $163 \cdot 1$ \\
$\quad($ rate $)$ & $(51 \cdot 2 \%)$ & $(63 \cdot 1 \%)$ & $(56.4 \%)$ \\
Correlation $(r)$ between initial and final sizes & 0.962 & $0 \cdot 833$ & 0.922 \\
\hline
\end{tabular}

${ }^{*} P<0.05$ compared with initial size.

The counts of the number of cells in 14 embryos that had increased in size during culture gave similar values for embryos with ( $534 \pm 86$ cells, $\mathrm{N}=7$ ) or without ( $538 \pm 86$ cells, $\mathrm{N}=7$ ) glucose uptake. It was not possible to see any morphological differences between the 2 groups of embryos that enlarged in culture. Of the 59 embryos used, $11(18.7 \%)$ failed to enlarge in culture. The mean ( \pm s.e.m.) initial size of these embryos was $305.3 \pm 47.6 \mu \mathrm{m}$. Only 2 embryos 
(initial sizes, 162 and $678 \mu \mathrm{m}$ ) took up glucose from the medium $(3.15$ and $10.3 \mu \mathrm{g} / \mathrm{h}$ respectively); the 9 other embryos showed no glucose uptake.

The development of embryos in vivo after cervical transfer is shown in Table 3. Significantly more embryos which exhibited uptake developed than did those with no glucose uptake.

Table 3. Development of cultured bovine embryos after single cervical transfer

\begin{tabular}{lccc}
\hline & $\begin{array}{c}\text { Embryos showing } \\
\text { glucose uptake }\end{array}$ & $\begin{array}{c}\text { Embryos with no } \\
\text { glucose uptake }\end{array}$ & Total \\
\hline $\begin{array}{l}\text { No. of recipients } \\
\begin{array}{l}\text { No. of pregnancies at Day } 50 \\
\text { (\%) }\end{array}\end{array}$ c $^{*}$ & 14 & 27 \\
\hline
\end{tabular}

* Significantly different $\left(\chi^{2}=6 \cdot 30 ; P<0.025\right)$.

$\dagger$ Including 1 dead fetus.

\section{Discussion}

When Day 10-11 (hatched) blastocysts were cultured for $20 \mathrm{~h}, 80 \%$ of them increased in size. The final mean size was not significantly different from that of freshly collected Day-12 embryos (455 $\pm 41.4 \mu \mathrm{m}, N=20$, unpublished data). A previous study showed that Day-10 embryos with a mean rate of increase in size of more than $50 \%$ during $24 \mathrm{~h}$ of culture had a significantly higher mean number of cells $(+27 \%)$ than did freshly collected Day-10 blastocysts (Renard, Menezo, Saumande \& Heyman, 1978) and therefore increase in size does reflect some degree of development of the embryos during culture. However, the pregnancy rate achieved at Day 50 after transfer of individual embryos developed in vitro $(40.7 \%)$ was lower than that obtained by direct transfer of uncultured embryos for which pregnancy rates of $50 \%$ resulted from surgical (Betteridge, Mitchell, Eaglesome \& Randall, 1976) and cervical (Renard ot al., 1977) transfers, although the figure for transferred blastocysts which took up glucose was higher $(69 \cdot 2 \%)$.

Blastocysts cultured for $20 \mathrm{~h}$ develop more slowly in vitro than in vivo, the cell number of cultured Day-10 embryos being lower than that of uncultured embryos of the same size (Renard et al., 1978), suggesting that optimal culture conditions have not yet been achieved. Groups of embryos which did not differ morphologically either before or after culture nevertheless exhibited different metabolic activity as demonstrated by glucose uptake in culture, corresponding to different potentialities for development after transfer. The low percentage of embryos that showed glucose uptake (46.9\%) is presumably related to the culture conditions, as well as to the percentage of viable embryos at recovery.

In the mouse, glucose is a necessary factor in vitro for the hatching of blastocysts (Wordinger \& Brinster, 1976) and this requirement may be related to a need for synthesis of glycogen (Ozias \& Stern, 1973; Pike \& Wales, 1973) and lipids (Flynn \& Hillman, 1978). In the rabbit, glucose metabolism increases greatly during the period of rapid expansion of the blastocyst (Brinster, 1968). Assays carried out on Day-13 cow blastocysts revealed that $85 \%$ (12/14) had significant glucose uptake (unpublished data) with a wide range of variability (4.7-50 $\mu \mathrm{g} / \mathrm{h} / \mathrm{embryo}$ ). These observations suggest that more accurate assessment could be obtained by using slightly older embryos; glucose uptake by Day-12-13 embryos cultured for periods of less than $20 \mathrm{~h}$ will be studied.

We thank Viviane Garnier and Marie-Claire Theron for skilful technical assistance and Aline Solari for performing the statistical analysis of the data. We are grateful to Dr R. M. Moor for reading and criticizing the manuscript. 


\section{References}

Betteridge, K.J., Mitchell, D., Eaglesome, M.D. \& Randall, G.C.G. (1976) Embryo transfer in cattle 10-17 days after estrus. Proc. 8th Int. Congr. Anim. Reprod.\& A.I., Krakow, Vol. III, pp. 237-240.

Brinster, L. (1968) Carbon dioxide production from glucose by the preimplantation rabbit embryo. Expl Cell Res. 51, 330-334.

Elsden, R.P., Nelson, L.D. \& Seidel G.E., Jr (1978) Superovulating cows with follicle stimulating hormone and pregnant mare's serum gonadotrophin. Theriogenology 9, 17-26.

Flynn, T.J. \& Hillman, N. (1978) Lipid synthesis from $\left[\mathrm{U}^{14}\right]$ glucose in preimplantation mouse embryos in culture. Biol. Reprod. 19, 922-926.

Menezo, Y. (1976) Mise au point d'un milieu artificiel défini pour la survie et la maturation des gamètes et pour la culture de l'oeuf fécondé. C. r. hebd. Séanc. Acad. Sci. Paris D 282, 1967-1970.

Ozias, C.B. \& Stern, S. (1973) Glycogen levels of preimplantation mouse embryos developing in vitro. Biol Reprod. 8, 467-472.

Ozil, J.P., Heyman, Y. \& Renard, J.P. (1979) An instrument for heifers embryo recovery by cervical route. Theriogenology 11, 173-183.

Pike, I.L. \& Wales, R.G. (1973) The effect of exogenous substrate on the metabolism of glycogen during early development of the preimplantation mouse embryo. J. Reprod. Fert. 35, 273-287.
Renard, J.P. \& du Mesnil du Buisson, F. (1976) Culture and storage of cow embryo. Proc. 8th Int. Congr. Anim. Reprod. \& A.I., Krakow, Vol. III, pp. 309312.

Renard, J.P., Heyman, Y. \& du Mesnil du Buisson, F. (1977) Unilateral and bilateral cervical transfer. Theriogenology 7, 189-194.

Renard, J.P., Menezo, Y., Saumande, J. \& Heyman, Y. (1978) Attempts to predict the viability of cattle embryos produced by superovulation. In Control of Reproduction in the Cow, pp. 398-417. Ed. J. R. Sreenan. Commission of the European Communities, Martinus Nighoff, The Hague.

Shea, B.F., Hines, DJ., Lightfoot, D.E., Ollis, G.W. \& Olson, S.M. (1976) The transfer of bovine embryos. In Egg Transfer in Cattle, pp. 145-152. Ed. L. E. A. Rowson. Commission of the European Communities, Luxembourg.

Trounson, A.O., Willadsen, S.M., Rowson, L.E.A. \& Newcomb, R. (1976) The storage of cow eggs at room temperature and at low temperatures. $J$. Reprod. Fert. 46, 173-178.

Wordinger, RJ. \& Brinster, R.L. (1976) Influence of reduced glucose levels on the in vitro hatching of the mouse blastocyst. Devl Biol. 53, 294-296.

Received 25 April 1979 